\title{
Impact of climate change scenario on rice production in two planting methods: a simulation study
}

\author{
A. Sumathi $\cdot$ S. Mohandass $\cdot$ S. Ramasamy
}

Received: 8 October 2012/Revised: 28 August 2013/Accepted: 11 January 2014/Published online: 4 February 2014

(C) Islamic Azad University (IAU) 2014

\begin{abstract}
In the present study, attempts have been made to simulate the effect of climate change on rice growth and yield, under both control and water-stressed conditions. Between the two planting methods, the system of rice intensification (SRI) practice had an advantage for the elevated $\mathrm{CO}_{2}$ conditions, with an additional yield of $1,325 \mathrm{~kg} \mathrm{ha}^{-1}$; while it was only $391 \mathrm{~kg} \mathrm{ha}^{-1}$ under traditional system of planting rice (TPR). Similarly, the yield decline due to temperature increment was $-2.0,-2.4$, -6.2 and $-12.8 \%$ under SRI practice as compared to that of $-4.0,-9.9,-11.3$ and $-31.7 \%$ in the TPR system for $+1,+2,+3$ and $+4{ }^{\circ} \mathrm{C}$ temperature rise, respectively. Thus, doubling of atmospheric $\mathrm{CO}_{2}$ level will compensate for the detrimental effect of increased temperature up to $2{ }^{\circ} \mathrm{C}$ in the SRI method of rice cultivation as compared to TPR system of planting. Thus, SRI practice is the most suitable method of rice cultivation under both elevated $\mathrm{CO}_{2}$ and temperature level. Simulation analysis of the present data using the dynamic model, ORYZA2000, indicated that under future adverse climatic conditions, the grain yield showed little variation $(+1.83 \%)$ with doubled $\mathrm{CO}_{2}$ at $+2{ }^{\circ} \mathrm{C}$ temperature rise especially with the water stress situations. However, this could be further raised
\end{abstract}

\footnotetext{
A. Sumathi $(\bowtie)$

Department of Crop Physiology, Tamil Nadu Agricultural University, Coimbatore 641003, India

e-mail: suma_arjunan@yahoo.co.in

S. Mohandass

Water Technology Centre, Tamil Nadu Agricultural University, Coimbatore 641003, India

S. Ramasamy

Department of Agronomy, Tamil Nadu Agricultural University, Coimbatore 641003, India
}

$(+17.10 \%)$ with the supplementation of pink-pigmented facultative methylotroph bacterium (PPFM) bio-fertilizer in the given scenario. Thus, temperature-induced yield alterations especially under water-stressed environment could be favorably mitigated with the $\mathrm{CO}_{2}$ fertilization along with the supplementation of PPFM bio-fertilizer.

Keywords Crop modeling - Elevated carbon dioxide . ORYZA2000 - System of rice intensification .

Temperature $\cdot$ Water stress

\section{Introduction}

Water-deficit environment is one of the most serious factors limiting production and productivity of rice, especially under transplanted lowland ecosystem. Further, lowland rice fields have relatively high water requirements, and their sustainability is threatened by increasing water scarcity (Bouman et al. 2001). Thus, there is an urgent need to develop water-saving irrigation strategies, and a new method of cultivation must be identified to seek higher productivity. System of rice intensification (SRI), a new approach, is one such practice which helps to economize the irrigation water. SRI technique was first developed at Madagascar about 20 years ago by Fr. Henri de Laulanine, S.J. along with the farmers. Yield with the SRI has been typically around $8 \mathrm{tha}^{-1}$, whereas the national average was only $2 \mathrm{t} \mathrm{ha}^{-1}$ (Hirch 2000). The most widely promoted water-saving technology in SRI is alternate wetting and drying (AWD); instead of keeping the fields always under submerged condition, the soil is allowed to dry-out for a few days after disappearance of the irrigated water, before it is flooded again. Recent results indicated that under SRI method of cultivation, about 42 and $50 \%$ of irrigation 
water could be saved over the integrated crop management and conventional method, respectively (Annie Poonam and Rao 2007), which ultimately reduced the cost of production to half, over the conventional cultivation.

Rice growth and yield under optimal conditions are largely determined by weather during the growing season. Carbon dioxide concentration in the atmosphere had increased considerably since pre-industrial times with current mean annual increment of about $1.5 \mathrm{ppm}$ (Keeling et al. 1984). According to the current model predictions, the increase in $\mathrm{CO}_{2}$ and other greenhouse gases was likely to rise the earth's temperature over the next 50 years, with concurrent changes in precipitation patterns. Climate change, via increasing atmospheric $\mathrm{CO}_{2}$ concentration, can affect global agricultural production by affecting photosynthesis (Cure and Acock 1986) and transpiration rates (Sionit et al. 1980). Increase in temperature speedup the plant development and alternatively decreases the duration of the grain-filling period (Stansel and Fries 1980). Thus, an increase in the daily mean temperature might reduce the crop yield potential in many areas. The combined effects of elevated $\mathrm{CO}_{2}$ with increasing temperature on the crop growth and productivity were partly unknown and were currently under investigation.

Field experimentation and simulation modeling are a powerful combination to understand complex crop-water interactions and to extrapolate site-specific empirical results to other environments and conditions. The rice growth model ORYZA2000 has been used to quantify trade-offs between yield and water usage and to distinguish between "real" water savings in depletion flows and to extrapolate empirical results in relation to different weather and hydrological conditions (Feng et al. 2007). Bouman et al. (2007) used ORYZA2000 to extrapolate the experimental results to other years and hydrological conditions and explored options to reduce water inputs and depletion flows for maintaining higher yields in rice.

Effect of various treatment combinations on growth and yield of a given variety to varied atmospheric locations are possible through simulation models. Further, models are the best tools to synthesize current knowledge and hypotheses to estimate directional trends for potential changes in rice yield due to climate change. In this article, we present the findings of the field experiments and parameterization and evaluation of ORYZA2000 model according to the future climate change scenario.

The present study was conducted in the Tamil Nadu Agricultural University (TNAU), Coimbatore, India, during wet and dry Season of 2006-2007 using the rice varieties CO 43 (135-140 days) and ADT 43 (115-120 days), respectively.

\section{Materials and methods}

\section{Field experiment}

The field experiments were conducted in the TNAU, Coimbatore, India, during wet and dry Season of 2006-2007 using the rice varieties CO 43 (135-140 days) and ADT 43 (115-120 days), respectively. The experiments were conducted on clay-loam soil in low-land rice area at wet land, Central Farm of TNAU $\left(11^{\circ} \mathrm{N}, 77^{\circ} \mathrm{E}\right.$; $426.72 \mathrm{~m}$ altitude). In the present study, both SRI and TPR methods of rice cultivation were practiced. In TPR, 20-dayold seedlings were transplanted at a spacing of $20 \mathrm{~cm} \times 10 \mathrm{~cm}$ and $15 \mathrm{~cm} \times 10 \mathrm{~cm}$ during both wet and dry season, respectively. In SRI, 14-day-old seedlings were transplanted at $25 \mathrm{~cm} \times 25 \mathrm{~cm}$ spacing in both the season. The experiments were laid out in a split plot design, replicated thrice with water management practices as the main plot treatments and mitigation practices in the sub-plot treatments. Size of the each plot was measured $4 \mathrm{~m} \times 5 \mathrm{~m}$. The experimental plots were laid out with double channels (buffer channels) around all the plots to prevent sub-soil lateral water flow. The main plot includes: "SRI" planting + recommended irrigation schedule $\left(\mathrm{M}_{1}\right)$, "SRI" planting + modified irrigation schedule $\left(\mathrm{M}_{2}\right)$, TPR planting + recommended irrigation schedule $\left(\mathrm{M}_{3}\right)$ and TPR planting + modified irrigation schedule $\left(\mathrm{M}_{4}\right)$. For the SRI and TPR method of planting, the recommended irrigation plots were irrigated up to 2 and $5 \mathrm{~cm}$ depth 1 day after disappearance of irrigated water, respectively. In the former case, this was pursued up to flowering. Thereafter, irrigation was given to $5 \mathrm{~cm}$ depth until 7 days before harvest.

For the modified irrigation schedule $\mathrm{M}_{2}$ and $\mathrm{M}_{4}$ plots, the water stress was imposed in two phases, viz. first one during panicle initiation (60-80 days after sowing (DAS) for CO 43 during wet season (WS) and 50-65 DAS for ADT 43 variety during dry season (DS) and second one during flowering stage (95-115 DAS for WS and 80-95 DAS for DS) by with-holding irrigation at the specified stages for both seasons. The stress was imposed 1 day after disappearance of irrigated water, during panicle initiation and flowering stage. Whenever rain fall was received during the stress period, the rain water was immediately drained off from the respective plots without allowing the rain water to percolate down the soil.

After the termination of the stress period, the stressed plots were re-irrigated to the required depth immediately in both SRI and TPR methods of planting, during both seasons as specified above. In both non-stressed and stressed plots, irrigation was suspended 7 days before the expected time of harvest. 
The sub-plot treatments, viz. control $\left(\mathrm{S}_{1}\right), 0.5 \mathrm{ppm}$ brassinolide (BR; $\left.\mathrm{S}_{2}\right), 100 \mathrm{ppm}$ salicylic acid $\left(\mathrm{SA} ; \mathrm{S}_{3}\right)$, $1 \%$ Potassium chloride $\left(\mathrm{KCl} ; \mathrm{S}_{4}\right)$ and spray of pink-pigmented facultative methylotroph (PPFM; $\mathrm{S}_{5}$ ) bacterial isolate load of $10^{6}$ at $1 \mathrm{ml}^{-1}$ were imposed at both panicle initiation and flowering stages 1 day after imposing the stress. Plant samples were drawn at the chosen stages for recording various morphological and physiological parameters by adopting standard procedure (Yoshida et al. 1971).

\section{Crop simulation modeling}

\section{Model description}

For the present study, an eco-physiological model, ORYZA2000, is used that simulates the growth, development and water balance of rice in situations of potential production and water limitations with time steps of 1 day (Bouman et al. 2001). It is assumed that the crop is well protected against diseases, pests and weeds. A detailed description of the model is given by Bouman et al. (2001) and a brief description of the model is given below.

In the ORYZA2000 model, crop phenology, leaf area index (LAI), partitioning of dry matter and quantity of water applied during the crop period were taken as the forcing functions. Water stress effects on leaf expansion, leaf rolling, leaf senescence and photosynthesis, assimilate partitioning, root growth and spikelet sterility were calculated as a function of the soil water tension in the root zone, using the module PADDY for computing the soil water dynamics of the puddle lowland soils (Wopereis et al. 1996; Bouman et al. 2001). The water retention and conductivity characteristics are expressed by Van Genuchten parameters (Van Genuchten 1980).

\section{Model parameterization}

The model ORYZA2000 was parameterized following the procedure of Bouman and Van Laar (2006). The crop and water applied data for $M_{1} \times S_{1}, M_{1} \times S_{5}, M_{2} \times S_{1}$, $M_{2} \times S_{5}, \quad M_{3} \times S_{1}, \quad M_{3} \times S_{5}, M_{4} \times S_{1}$ and $M_{4} \times S_{5}$ treatments for WS (CO 43) and DS (ADT 43) were used for parameterization of the model. Development rates were calculated using the recorded dates of sowing, transplanting, panicle initiation, flowering and maturity in each treatment. In the case of non-stressed control treatments, the model ORYZA2000 was run for the potential production situation. Data on LAI and partitioning of dry matter among leaf, Culm, root and panicles, used as forcing functions in the model, were taken for the above treatments and parameterized in the model. In the case of waterstressed treatments, the quantity of water applied was used as forcing function in addition to the data on other chosen parameters. In the present study, the water balance was computed using Penman's water balance equation for different treatments. Such quantification is essential for calculating the amount of water going into the atmosphere through evaporation and transpiration in the chosen treatments (Bouman et al. 2001). In the present study, water balance was computed using Penman's water balance equation for different treatments. Such quantification is essential for calculating the amount of water going into the atmosphere through evaporation and transpiration in the chosen treatments.

\section{Model evaluation}

The performance of ORYZA2000 was evaluated for the chosen treatments in both the seasons using the corresponding required weather data. The model was also used to extrapolate to the future climate change scenario of elevated atmospheric $\mathrm{CO}_{2}(680 \mathrm{vppm})$ level and temperature increase (up to $+4.0^{\circ} \mathrm{C}$ ). The results of simulated grain yield and seasonal water use are presented and discussed in Tables 1 and 2 .

\section{Results and discussion}

Crop simulation modeling

\section{Model validation}

Simulated grain yield of the chosen treatments are furnished in Table 1 along with the observed grain yield.

The results indicated that there was a fair agreement (direct correlation may be used) between simulated and observed grain yields for DS (ADT 43), while the agreement showed wide variation for WS (CO 43). Similar results were observed by Srivastava et al. (2004) showing good agreement between observed and simulated grain yields in DS rather than WS. Therefore, further simulation runs, described in the following paragraphs, were made with special reference to DS for future climate change scenarios, based on the results of model validation.

\section{Quantification of water flux}

In the present simulation study, total water use, evaporation (EP) and transpiration (T) during DS have been quantified using ORYZA2000 model for irrigated rice ecosystem (Table 2). With the help of the model, the water flux has been quantified for the chosen treatments during DS (2007). Penman's water balance equations have been used in the model for this computation. 
Table 1 Validation of grain yield $\left(\mathrm{kg} \mathrm{ha}^{-1}\right)$ simulated by ORYZA2000 model in two different seasons using parameters of chosen treatments

\begin{tabular}{lllll}
\hline Treatments & \multicolumn{2}{l}{ Wet season (CO 43) } & & \multicolumn{2}{l}{ Dry season (ADT 43) } \\
\cline { 2 - 3 } & Observed yield & Simulated yield & Observed yield & Simulated yield \\
\hline $\mathrm{M}_{1} \times \mathrm{S}_{1}$ & 6,081 & $\uparrow 8,580(41.10 \%)$ & 6,219 & $\uparrow, 983(12.28 \%)$ \\
$\mathrm{M}_{2} \times \mathrm{S}_{5}$ & 7,019 & $\uparrow 9,971(42.09 \%)$ & 6,923 & $\uparrow 5,541(8.35 \%)$ \\
$\mathrm{M}_{2} \times \mathrm{S}_{1}$ & 4,990 & $\uparrow 5,404(8.30 \%)$ & 5,114 & $\uparrow 6,430(3.84 \%)$ \\
$\mathrm{M}_{3} \times \mathrm{S}_{5}$ & 6,109 & $\downarrow 5,923(-3.04 \%)$ & 6,192 & $\uparrow 6,679(11.74 \%)$ \\
$\mathrm{M}_{3} \times \mathrm{S}_{1}$ & 6,019 & $\uparrow 10,162(68.83 \%)$ & 5,977 & $\uparrow 7,171(10.73 \%)$ \\
$\mathrm{M}_{4} \times \mathrm{S}_{5}$ & 6,798 & $\uparrow 10,511(54.62 \%)$ & 6,476 & $\uparrow 5,690(21.56 \%)$ \\
$\mathrm{M}_{4} \times \mathrm{S}_{1}$ & 4,035 & $\uparrow 9,992(147.63 \%)$ & 4,680 & $\uparrow 6,337(12.26 \%)$ \\
$\mathrm{M}_{1} \times \mathrm{S}_{5}$ & 5,731 & $\uparrow 10,520(85.56 \%)$ & 5,645 & \\
\hline
\end{tabular}

Figures in parentheses indicate \% deviation from the observed yield estimates. Up-arrows $(\uparrow)$ indicate overestimation and down arrow $(\downarrow)$ indicates underestimation. $\mathrm{M}_{1}$ - SRI with conventional irrigation, $\mathrm{M}_{2}-\mathrm{SRI}$ with stress at PI and $\mathrm{FF}, \mathrm{M}_{3}-\mathrm{TPR}$ with conventional irrigation, $\mathrm{M}_{4}$ - TPR with stress at PI and FF, $\mathrm{S}_{1}$ - control, $\mathrm{S}_{5}-10^{6}$ PPFM bacterial isolate. In both cases, an estimate of $<25 \%$ represents good approximation of the reported yield (Srivastava et al. 2004)

Table 2 Values of observed and simulated total water used by ORYZA2000 for the chosen treatments, DS (2007)

\begin{tabular}{lcr}
\hline Treatments & $\begin{array}{l}\text { Observed total } \\
\text { water use }(\mathrm{mm})\end{array}$ & $\begin{array}{l}\text { Simulated total } \\
\text { water use }(\mathrm{mm})\end{array}$ \\
\hline $\mathrm{M}_{1} \times \mathrm{S}_{1}$ & 620 & $\uparrow 640(3.22 \%)$ \\
$\mathrm{M}_{1} \times \mathrm{S}_{5}$ & 620 & $\uparrow 640(3.22 \%)$ \\
$\mathrm{M}_{2} \times \mathrm{S}_{1}$ & 470 & $\uparrow 486(3.40 \%)$ \\
$\mathrm{M}_{2} \times \mathrm{S}_{5}$ & 470 & $\uparrow 486(3.40 \%)$ \\
$\mathrm{M}_{3} \times \mathrm{S}_{1}$ & 1,070 & $\downarrow 1,050(1.87 \%)$ \\
$\mathrm{M}_{3} \times \mathrm{S}_{5}$ & 1,070 & $\uparrow 1,100(2.80 \%)$ \\
$\mathrm{M}_{4} \times \mathrm{S}_{1}$ & 820 & $\downarrow 700(14.63 \%)$ \\
$\mathrm{M}_{4} \times \mathrm{S}_{5}$ & 820 & $\downarrow 700(14.63 \%)$
\end{tabular}

Figures in parentheses indicate \% deviation from the observed estimates. Up-arrows $(\uparrow)$ indicate overestimation and down arrow $(\downarrow)$ indicates underestimation. $\mathrm{M}_{1}-\mathrm{SRI}$ with conventional irrigation, $\mathrm{M}_{2}$ - SRI with stress at PI and FF, $\mathrm{M}_{3}$ - TPR with conventional irrigation, $\mathrm{M}_{4}-\mathrm{TPR}$ with stress at PI and FF, $\mathrm{S}_{1}-$ control, $\mathrm{S}_{5}-10^{6}$ PPFM bacterial isolate. In both cases, an estimate of $<25 \%$ represents good approximation of the reported values (Srivastava et al. 2004)

The values for the chosen treatments indicated fairly a good agreement between observed and simulated ones, for the total water use, in both the planting systems for nonstressed as well as stressed treatments.

\section{Scenario analysis: elevated $\mathrm{CO}_{2}$ and temperature}

Anthropogenic influences including rapid industrialization, urbanization, and combustion of fossil fuels, mining and deforestation have released enormous quantities of carbon dioxide $\left(\mathrm{CO}_{2}\right)$, methane $\left(\mathrm{CH}_{4}\right)$ and other "greenhouse" gases into the atmosphere. This in turn might have serious implications that lead to global warming with the consequent rise in earth's temperature (by $1-4{ }^{\circ} \mathrm{C}$ ) which could have significant impact on the delicate balance of agricultural production systems that are so intricately associated with the weather system causing imbalance in food supply. Hence, it is imperative to study the effects of climate change on the yield of staple food crops such as rice. Objective of the following study was to understand the impacts of future climate on the rice production especially in relation to limited water supply situations.

The dynamic simulation model ORYZA2000 was evaluated under potential and N-limited conditions in the Philippines (Bouman and Van Laar 2006), under conditions of alternate wetting and drying AWD irrigation in China (Belder et al. 2007) and under N-limited and rainfed conditions in Indonesia (Boling et al. 2007). Different climate change scenarios (Matthews et al. $1995 \mathrm{a}, \mathrm{b}, \mathrm{c})$ resulting from changes in temperature and atmospheric $\mathrm{CO}_{2}$ concentrations were evaluated with ORYZA2000 model for their impacts on rice cultivation. Estimates were made to quantify the effect of $\mathrm{CO}_{2}$ rise and temperature on the yield of rice grown in the DS of Coimbatore site. The details of different scenarios employed in the present simulation study are furnished below.

Scenarios used for both SRI and TPR systems of planting:

1. Current $\mathrm{CO}_{2} 340$ vppm at $+1,+2,+3$ and $+4{ }^{\circ} \mathrm{C}$

2. Current $\mathrm{CO}_{2}+$ stress at $+1,+2,+3$ and $+4{ }^{\circ} \mathrm{C}$

3. Current $\mathrm{CO}_{2}+$ stress + PPFM at $+1,+2,+3$ and $+4{ }^{\circ} \mathrm{C}$

4. $\times 2 \mathrm{CO}_{2} 680$ vppm at $+1,+2,+3$ and $+4{ }^{\circ} \mathrm{C}$

5. $\times 2 \mathrm{CO}_{2}$ at + stress at $+1,+2,+3$ and $+4{ }^{\circ} \mathrm{C}$

6. $\times 2 \mathrm{CO}_{2}+$ stress + PPFM at $+1,+2,+3$ and $+4{ }^{\circ} \mathrm{C}$. 


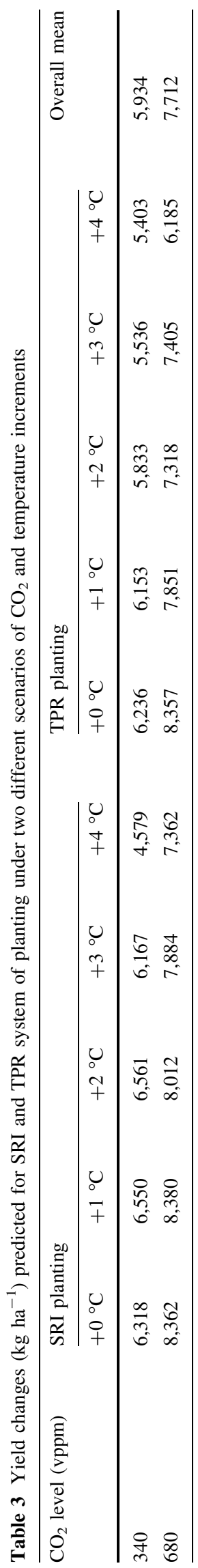

Effect of two varied levels of $\mathrm{CO}_{2}$ and temperature by fixed increments were simulated using ORYZA2000 model. The simulation analysis was done using the daily weather data of Coimbatore Observatory. The dates of sowing and transplanting were selected as adopted in the field experiments during DS (2007). The results are presented in the Table 3 .

Analysis of data from simulation studies indicates that there was a general increase in the grain yield with twofold rise of $\mathrm{CO}_{2}$ level at all stage of temperature increment (Table 3). Between the planting methods, the SRI practice had an edge over the TPR system of planting. It was also inferred that the temperature-induced yield reduction, especially beyond $+2{ }^{\circ} \mathrm{C}$ range, could be safely moderated with the elevated level of $\mathrm{CO}_{2}$ in both the system of planting.

An increase in temperature reduces the grain yield in both the methods of planting, but the temperature effect was more drastic in TPR system than the SRI practice. For example, there was reduction in grain yield of SRI planting at +2 and $+4{ }^{\circ} \mathrm{C}$ of temperature, and the reduction was only -2.4 and $-12.8 \%$, respectively. However, with the same temperature increase, the reduction was -9.9 and $-31.7 \%$, respectively, in the case of TPR system of planting (Table 4).

With respect to the water stress environment, the change in grain yield due to the stress was -20.3 and $-19.8 \%$ with 340 and $680 \mathrm{vppm}$, respectively. Thus, the waterstress-induced yield reduction was only marginal between current as well as increased $\mathrm{CO}_{2}$ levels. Nevertheless, such reduction could be significantly narrowed down to -8.8 and $7.7 \%$, respectively, with the supplementation of PPFM bio-fertilizer for stress mitigation in the future climate change scenarios (Table 5).

Climate change is likely to have a significant impact on agricultural production depending upon the magnitude of temperature and $\mathrm{CO}_{2}$ increase. The impact of global climate change on agriculture has been studied extensively for various crops at different scales (Lemon 1983; Acock and Allen 1985). However, relatively fewer studies have been focused on rice (Baker and Allen 1993; Horie 1993; Kropff et al. 1993; Mohandass et al. 1993; Penning de Vries 1993). An adverse effect of climate change on rice production had also been reported by Matthews et al. (1995a). Srivastava et al. (2004) analyzed the effects of

Table 4 Yield changes (\%) predicted for SRI and TPR systems of planting under fixed temperature increments

\begin{tabular}{llllll}
\hline Planting method & $+0{ }^{\circ} \mathrm{C}$ & $+1{ }^{\circ} \mathrm{C}$ & $+2{ }^{\circ} \mathrm{C}$ & $+3{ }^{\circ} \mathrm{C}$ & $+4{ }^{\circ} \mathrm{C}$ \\
\hline SRI & 0 & -2.0 & -2.4 & -6.2 & -12.8 \\
TPR & 0 & -4.0 & -9.9 & -11.3 & -31.7 \\
\hline
\end{tabular}


Table 5 Simulated changes in grain yield due to water stress and ameliorative treatments under two different $\mathrm{CO}_{2}$ scenarios

\begin{tabular}{|c|c|c|c|c|}
\hline \multirow[t]{2}{*}{ Treatments } & \multicolumn{2}{|c|}{340 vppm $\mathrm{CO}_{2}$ level } & \multicolumn{2}{|c|}{680 vppm $\mathrm{CO}_{2}$ level } \\
\hline & $\begin{array}{l}\text { Grain yield } \\
\left(\mathrm{kg} \mathrm{ha}^{-1}\right)\end{array}$ & $\begin{array}{l}\text { Change } \\
(\%)\end{array}$ & $\begin{array}{l}\text { Grain yield } \\
\left(\mathrm{kg} \mathrm{ha}^{-1}\right)\end{array}$ & $\begin{array}{l}\text { Change } \\
(\%)\end{array}$ \\
\hline Control (no stress) & 6,570 & 0.0 & 8,426 & 0.0 \\
\hline Water stressed & 5,238 & -20.3 & 6,758 & -19.8 \\
\hline Stressed + PPFM & 5,993 & -8.8 & 7,776 & -7.7 \\
\hline
\end{tabular}

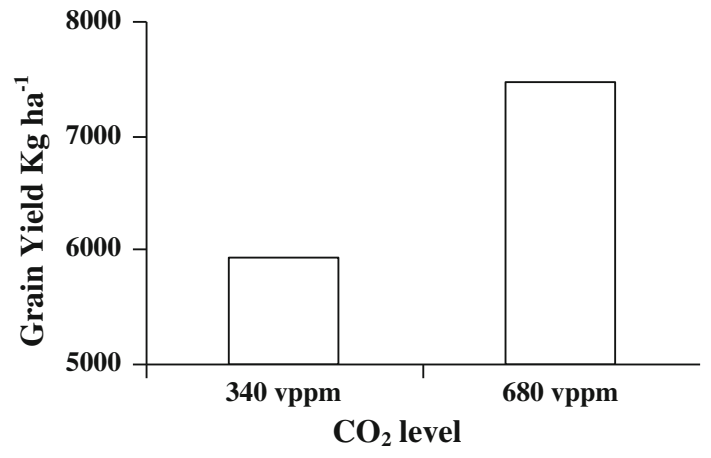

Fig. 1 Simulated grain yield under 340 and 680 vppm $\mathrm{CO}_{2}$ levels

elevated temperature and $\mathrm{CO}_{2}$ concentrations on the yield and water use of rice, grown in the three agro-ecologically different environments, to understand the possible impacts of climate change in rice based on agro-ecosystems. In the present study, an attempt has been made to simulate the climate change effects on rice production for both control and water-stressed situations. Simulation analysis indicated that there was a general increase in mean grain yield by $26.1 \%$ with doubling of $\mathrm{CO}_{2}$ than the current level (Fig. 1). On the contrary, the increment in temperature gradually reduced the yield by $-3.0,-6.1,-8.7$ and $-22.1 \%$ for $+1,+2,+3$ and $+4{ }^{\circ} \mathrm{C}$, respectively (Fig. 2).

Chamber experiment studies by Baker et al. (1990) showed increases in grain yield and biomass as $\mathrm{CO}_{2}$ concentration increases together with an increase in canopy net photosynthesis and water use efficiency. Simulation studies conducted by Mohandass et al. (1995) indicated that the annual national rice production of India was likely to increase as $\mathrm{CO}_{2}$ levels and temperature increase in future climates. Ranganathan and Mohandass (1997) suggested that altered crop phenology, early vigor, increased source size and its activity were found to be the efficient physiological traits for increasing yield plateau in the alleviation of temperature-induced detrimental effects of the future climate change scenarios.

Results from our studies indicate that between the two planting methods, the SRI practice had an advantage for the elevated $\mathrm{CO}_{2}$ conditions, with an additional yield of

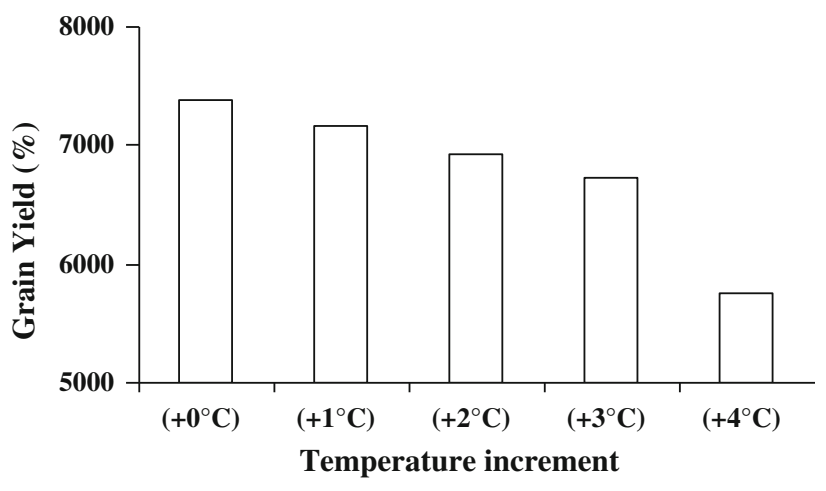

Fig. 2 Simulated grain yield with increment in temperature

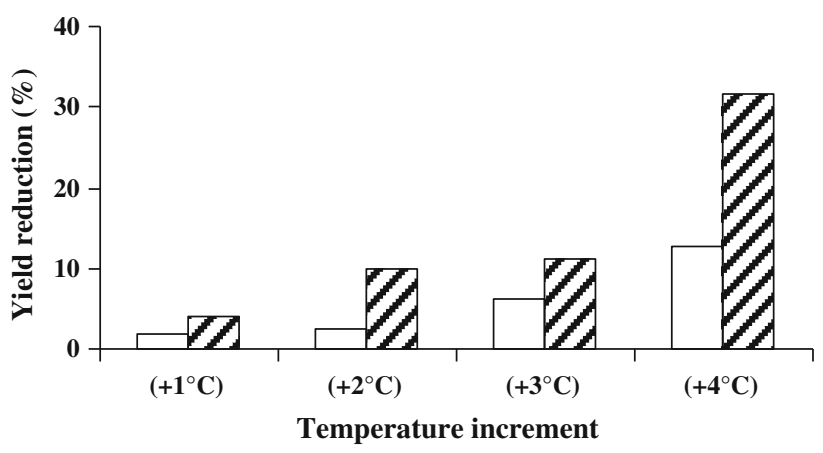

Fig. 3 Reduction in stimulated grain yield (\%) due to temperature increase in two different planting methods

$1,325 \mathrm{~kg} \mathrm{ha}^{-1}$; while it was only $391 \mathrm{~kg} \mathrm{ha}^{-1}$ under TPR system of planting with the doubled $\mathrm{CO}_{2}$ level. Similarly, the yield decline due to temperature increment was -2.0 , $-2.4,-6.2$ and $-12.8 \%$ for the SRI practice and -4.0 , $-9.9,-11.3$ and $-31.7 \%$ in the TPR system for $+1,+2$, +3 and $+4{ }^{\circ} \mathrm{C}$, respectively (Fig. 3).

In this content, doubling of atmospheric $\mathrm{CO}_{2}$ level was sufficient enough to compensate for the detrimental effect of increased temperature up to $2{ }^{\circ} \mathrm{C}$ for the SRI practice, but it was not alike in the TPR system of planting. Therefore, from the present study, it is clear that the yield in the TPR system of planting would be much more affected by an increase in $\mathrm{CO}_{2}$ level and the associated temperature increase as compared to that of the SRI practice (Fig. 4) in the future climates. Hence, in totality, it could be inferred that the SRI system of planting was better placed with regard to future climate change scenarios in terms of both elevated $\mathrm{CO}_{2}$ and temperature levels. This difference reflected that the higher temperatures, normally encountered during DS, would affect the crop productivity by increasing the percentage of spikelet sterility, and this could be a major factor limiting the crop yield. This is especially true for the TPR system of planting in the present investigation. 
Fig. 4 Combined effects of $\mathrm{CO}_{2} \times$ temperature on grain yield in two planting methods
Fig. 5 Predicted grain yield changes $(+$ or - ) in future climate change scenario in relation to current yield
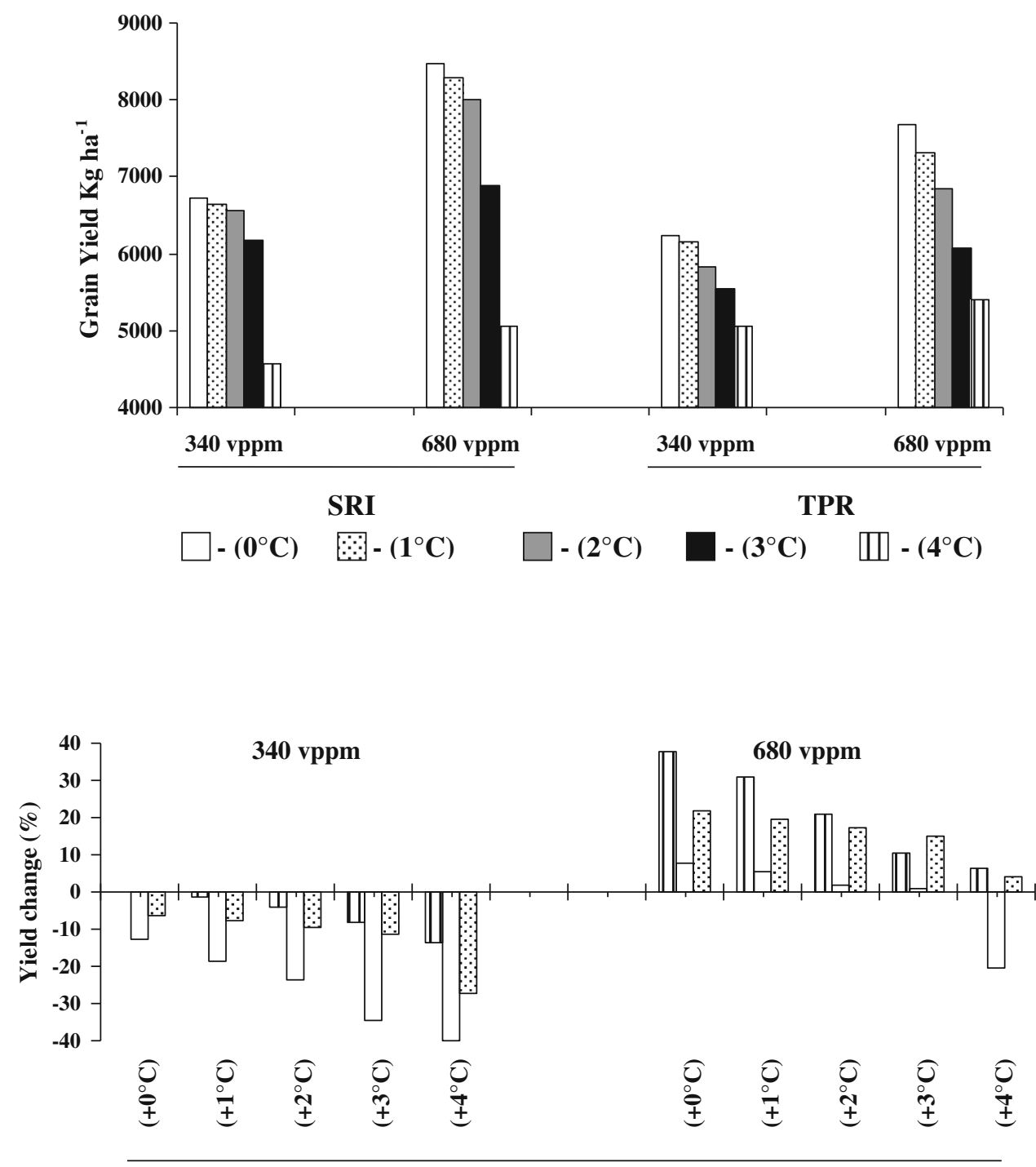

Temperature increment

Ш - Control

$\square$ - Stress $\quad \because$ - Stress + PPFM
In rice, spikelet fertility was influenced adversely by extreme temperatures immediately before and after flowering (Yoshida 1981). A reduction in spikelet fertility reduces the number of grains that could form, so that even if carbohydrate production in the grain-filling period was unaffected, yield was reduced (Matthews et al. 1995c). Similar reduction in spikelet fertility and modified crop duration due to temperature increase were observed by several authors (Kropff et al. 1994; Matthews et al. 1995b; Mohandass et al. 1995). Simulation analysis of combined effects of elevated $\mathrm{CO}_{2} \times$ temperature increase $\times$ water stress (Fig. 5) inferred that during the current climate of 340 vppm $\mathrm{CO}_{2}$ concentration and normal environment, the mean decrease in grain yield with the temperature gradient $+0,+1,+2,+3{ }^{\circ} \mathrm{C}$ and $+4{ }^{\circ} \mathrm{C}$ were $6.5,7.0,11.5,18.0$ and $26.9 \%$, respectively. On the other hand, increasing the
$\mathrm{CO}_{2}$ level to 680 vppm (double), increases the yield by $22.4,18.8,12.2$ and $11.6 \%$ with the respective temperature increment of $+0,+1,+2$ and $+3{ }^{\circ} \mathrm{C}$, although a slight decrease by $1.9 \%$ with $+4{ }^{\circ} \mathrm{C}$ was observed.

However, the yield reduction due to water stress with current atmospheric $\mathrm{CO}_{2}$ level (340 vppm) was -12.9 , $-18.6,-23.6,-34.6$ and $-39.8 \%$ with the temperature increment of $+0,+1,+2,+3$ and $+4{ }^{\circ} \mathrm{C}$, respectively. Such reduction could be narrowed down to $-6.6,-6.6$, $-9.5,-11.3$ and $-27.4 \%$ at the temperature increment of $+0,+1,+2,+3$ and $+4{ }^{\circ} \mathrm{C}$, respectively, with the supplementation of PPFM bio-fertilizer in the stressed treatments. Thus, the role of PPFM for both water and temperature stress situations was phenomenal in alleviating the stress effects in future climate. Similarly, for doubling of atmospheric $\mathrm{CO}_{2}$ concentration $(680 \mathrm{vppm})$, the 
Table 6 Range in values of transpiration and evaporation simulated by ORYZA2000 model during DS 2007

\begin{tabular}{|c|c|c|c|c|}
\hline \multirow[t]{2}{*}{ Treatments } & \multicolumn{2}{|l|}{ Transpiration } & \multicolumn{2}{|l|}{ Evaporation } \\
\hline & $\left(\mathrm{mm}\right.$ season $\left.^{-1}\right)$ & Percent total water applied & $\left(m m\right.$ season $\left.^{-1}\right)$ & Percent total water applied \\
\hline \multicolumn{5}{|l|}{ SRI method } \\
\hline Control & 459.8 & 71.9 & 180.2 & 28.1 \\
\hline Stressed & 310.5 & 63.9 & 175.5 & 36.1 \\
\hline \multicolumn{5}{|l|}{ TPR method } \\
\hline Control & 854.5 & 74.3 & 295.5 & 25.7 \\
\hline Stressed & 772.8 & 67.2 & 377.2 & 32.8 \\
\hline
\end{tabular}

predicted changes in the yield across temperature gradient with the stressed treatments were $+7.8,+5.7,+1.8,-0.3$ and $-20.4 \%$ with the temperature increment of $+0,+1$, $+2,+3$ and $+4{ }^{\circ} \mathrm{C}$, respectively. Possibility of increasing the yield under water stress situations was also evident with the supplementation of PPFM bio-fertilizer as noticed with the yield advantage by $+21.7,+19.6,+17.1,+15.0$ and -4.3 due to the temperature increment of $+0,+1,+2,+3$ and $+4{ }^{\circ} \mathrm{C}$, respectively.

Microorganisms that had the capacity to form intricate relationships with the plants produce significant quantities of plant growth regulators. Further, the bacteria removed metabolic waste products such as methanol from the apoplast of the host and using them as a nutritional source, degraded them into simple compounds, which were eventually returned to the plant (Holland 1997). The beneficial effects of PPFM on growth and development of crop plants had been attributed to the production of phytohormones (Holland 1997) and vitamin (Basile et al. 1985). While studying the potential of PPFM for cytokinin biosynthesis, Soumya (2005) revealed that the PPFM isolate produced trans-zeatin content and IAA production ranging from 22.04 to $117.32 \mathrm{ng} \mathrm{g}^{-1}$ and 0.14 to $4.69 \mu \mathrm{g} \mathrm{ml}^{-1}$ of culture filtrate, respectively. Thangamani (2005) reported that combined application of PPFM with $75 \% \mathrm{~N}$ and $\mathrm{P}$ and $100 \% \mathrm{~K}$ increased the growth and physiological parameters in terms of total chlorophyll, protein and phenol and also the activity of Urease enzyme in ADTRH 1 hybrid rice. Thus, through the simulation analysis, it can be presumed that the temperature-induced yield alterations in future climates especially under water-stressed environment could safely be narrowed down with the $\mathrm{CO}_{2}$ fertilization along with the supplementation of PPFM biofertilizer.

\section{Water flux}

Close observation of the data (Table 6) on water flux as simulated by the ORYZA2000 model for the current climate during DS indicated that, under non-stressed conditions, the share of crop transpiration and soil evaporation in the SRI practice was found to be 71.9 and $28.1 \%$, respectively, for the total water applied. Similar results were observed by Srivastava et al. (2004).

However, for the stressed treatments, the shares were 63.9 and $36.1 \%$ for transpiration and evaporation, respectively. Thus, the share of soil evaporation component was higher with the stressed treatments. Similar trend was observed for the TPR system of planting in both nonstressed and stressed scenarios with more shares for the transpiration component. Nevertheless, doubling of $\mathrm{CO}_{2}$ and temperature increment in future climates showed very little alterations for the values of soil evaporation and crop transpiration (data not shown) components.

\section{Conclusion}

A model study is needed to disentangle the interacting effects of rainfall, irrigation, soil type and groundwater depth on the performance of the water-saving technology, AWD. ORYZA2000 was sufficiently accurate in the simulation of crop growth and soil water dynamics under flooded lowland conditions at our test site for such a purpose. Based on the simulation analysis, it is found that the temperature-induced yield alterations in future climates especially under water-stressed environment could be favorably mitigated with the $\mathrm{CO}_{2}$ fertilization along with the supplementation of PPFM bio-fertilizer. Besides, the present investigation of simulation analysis had also paved a way for future research, taking into consideration that the identification of temperature-tolerant isolates of PPFM would prove to be much more beneficial in further raising the yield plateau as observed at the temperature increment of beyond $+2{ }^{\circ} \mathrm{C}$ level in the future climates.

Acknowledgments The authors thank Professor and Head, and faculty Department of Crop Physiology, TNAU, for providing all the 
infrastructures for the study. Also, the authors thank Professor and Head, Department of Agricultural Microbiology, for providing PPFM strain, and extend their gratitude to Professor and Farm manager (wet lands, TNAU) for allowing to conduct field experiments in the farm lands. The authors also thank Directorate of Research, TNAU, for funding this study and Dr. Biplab Adhikari, Scientist, Biochemistry division, TRA (Tea Research Association), Nagrakatta, West Bengal, India, for his comments and valuable suggestions.

\section{References}

Acock B, Allen LH Jr (1985) Crop responses to elevated carbon dioxide concentrations. In: Strain BR, Cure JD (eds) Direct effects of carbon dioxide on vegetation. DOE/ER-0238, U.S. Dept. of Energy, Caorbon dioxide Reseach Division, Washington, DC, pp 53-98

Poonam A, Rao KS (2007) System of rice intensification: a method for enhancing rice yield. In: Abstract national symposium on research priorities and strategies in rice production system for second green revolution held at Central Rice Research Institute, Cuttack, 20-22 November, pp 8-10

Baker JT, Allen LH Jr (1990) Growth and yield responses of rice to carbon dioxide concentration. J Agric Sci 115:313-320

Baker JT, Allen LH Jr (1993) Effect of $\mathrm{CO}_{2}$ and temperature on rice: a summary of five growing seasons. J Agric Meteorol 48:575-582

Basile DV, Basile MR, Li QY, Corpe WA (1985) Vitamin B B $_{12}$ simulated growth and development of Jungermannia leiantha Grolle and Gymnocolea inflata (Huds.) Dum. (Hepaticae). Bryologist 88:77-81

Belder P, Bouman BAM, Spiertz JHJ, Lu G (2007) Exploring options for water savings in lowland rice using a modelling approach. Agric Syst 92:91-114

Boling A, Bouman BAM, Tuong TP, Murty MVR, Jatmiko SY (2007) Modelling the effect of groundwater depth on yieldincreasing interventions in rainfed lowland rice in Central Java, Indonesia. Agric Syst 92:115-139

Bouman BAM, Van Laar HH (2006) Description and evaluation of the rice growth model ORYZA2000 under nitrogen-limited conditions. Agric Syst 87:249-273

Bouman BAM, Kropff MJ, Tuong TP, Wopereis MCS, Ten Berge HFM, Vann Laar HH (2001) ORYZA2000: modelling lowland rice. Wageningen University and Research Centre, Wageningen, p 235

Bouman BAM, Feng L, Tuong TP, Lu G, Wang H, Feng Y (2007) Exploring options to grow rice using less water in northern China using a modeling approach. II. Quantifying yield, water balance components and water productivity. Agric Water Manag 88:23-33

Cure JD, Acock B (1986) Crop responses to carbon dioxide doubling: a literature survey. Agric For Meteorol 38:127-145

Feng L, Bouman BAM, Tuong TP, Cabangon RJ, Li Y, Lu G, Feng Y (2007) Exploring options to grow rice using less water in northern China using a modeling approach. I. Field experiments and model evaluation. Agric Water Manage 88:1-13

Hirch R (2000) La riziculture malgache revistee: diagnostic et perspectives (1993-1999). Agence Francaise De Development, Antananrivo

Holland MA (1997) Methylobacterium and plants. Recent Res Dev Plant Physiol 1:207-213

Horie T (1993) Predicting the effects of climate variation and effect of $\mathrm{CO}_{2}$ on rice yield in Japan. J Agric Meteorol 48:567-574
Keeling CD, Carter AF, Mook WG (1984) Seasonal, latitudinal and secular variations in the abundance and isotopic ratios of atmospheric $\mathrm{CO}_{2}$. J Geophys Res 89:4615-4628

Kropff MJ, Cassman KG, Pennig de Vries FWT, Van Laar HH (1993) Increasing the yield plateau in rice and the role of global climate change. J Agric Meteorol 48:795-798

Kropff MJ, Van Laar HH, Matthews RB (1994) ORYZA1: an ecophysiological model for irrigated rice production. IRRI, Los Baños 110

Lemon ER (1983) $\mathrm{CO}_{2}$ and Plants: the response of plants to rising levels of atmospheric carbon dioxide. Westview Press, Boulder, $\mathrm{CO}$

Matthews RB, Kropff MJ, Bachelet D, Vann Laar HH (eds) (1995a) Modeling the impact of climate change on rice production in Asia. CAB International, Wallingford, p 289

Matthews RB, Kropff MJ, Bachelet D, Horie T, Lee MH, Centeno HGS, Shin JC, Mohandass S, Singh S, Defeng Z (1995b) Modelling the impact of climate change on rice production in Asia. In: Peng S, Ingram KT, Neue H-U, Ziska LH (eds) Climate change and rice. Springer, New York, pp 314-325

Matthews RB, Horie T, Kropff MJ, Bachelet D, Centeno HG, Shin JC, Mohandass S, Singh S, Defeng Z, Lee MH (1995c) A regional evaluation of the effect of future climate change on rice production in Asia. In: Matthews RB, Kropff MJ, Bachelet D, Vann Laar HH (eds) Modeling the impact of climate change on rice production in Asia. $\mathrm{CAB}$ International, Wallingford, pp 95-139

Mohandass S, Thiyagarajan TM, Palanisamy S, Abdul Kareem A (1993) Impact of increased temperature and $\mathrm{CO}_{2}$ on rice productivity in Cauvery delta zone, India - a simulation analysis. J Agric Meteorol 52:721-726

Mohandass S, Kareem AA, Ranganthan TB, Jayaraman S (1995) Rice production in India under current and future climates. In: Matthews RB, Kropff MJ, Bachelet D, Vann Laar HH (eds) Modeling the impact of climate change on rice production in Asia. CAB International, Wallingford, pp 165-181

Penning de Vries FWT (1993) Rice production and climate change. In: Penning de Vries FWT, Teng PS, Metselaar K (eds) Systems approaches for agricultural development, Kluwer Academic Publishers, Dordrecht, The netherlands, pp 175-192

Ranganathan TB, Mohandass S (1997) Identification of critical plant traits for rice ideotype development in future climates in Tamil Nadu, India. J Agric Meteorol 52:939-944

Sionit N, Hellmers H, Strain BR (1980) Growth and yield of wheat under $\mathrm{CO}_{2}$ enrichment and water stress. Crop Sci 20:456-458

Soumya VI (2005) Studies on the potential of pink pigmented facultative methylotrophs for cytokinins biosynthesis in association with plant tissue under in vitro conditions. Ph.D., thesis, Tamil Nadu Agricultural University, Coimbatore 641003, India

Srivastava SK, Meena Rani HC, Jayaraman V, Bandyopadhyay S, Phene SG, Mohandas S, Palanisamy K, Nayak SK, Paul JV (2004) Dynamics of biospheric aspect of hydrological cycle (BAHC) in rice agro-ecosystems of India. ISRO-GBP Scientific Report No. 10. Indian Space Research Organization (ISRO), Bangalore, p 92

Stansel JW, Fries RE (1980) A conceptual agromet rice yield model. In: Agrometeorology of rice crop. World meteorological organization and the international rice research institute, Los Baños, pp 201-212

Thangamani G (2005) Studies on facultative methylotrophs for increasing crop production. Ph.D. thesis submitted to Tamil Nadu Agricultural University, Coimbatore 641003, India

Van Genuchten MTh (1980) A closed-form equation for predicting the hydraulic properties of unsaturated soils. Soil Sci Soc Am J 44:892-898 
Wopereis MCS, Bouman BAM, Tuong TP, Ten Berge HFM, Kropff MJ (1996) ORYZA_W: rice growth model for irrigated and rainfed environments. In: SARP research proceedings, IRRI/ABDLO, Wageningen, Netherlands, p 159

Yoshida S (1981) Fundamentals of rice crop science. International Rice Research Institute, Los Baños, p 299
Yoshida S, Foron DA, Cock JH (1971) Laboratory manual for physiological studies of rice. International Rice Research Institute, Los Baños, p 70 